\title{
$\beta$-catenin plays a key role in metastasis of human hepatocellular carcinoma
}

\author{
TUNG-YUAN LAI ${ }^{1,5}$, CHENG-CHUAN SU $^{6-8}$, WEI-WEN KUO ${ }^{2}$, YU-LAN YEH ${ }^{9}$, WU-HSIEN KUO ${ }^{10}$, \\ FUU-JEN TSAI ${ }^{3}$, CHANG-HAI TSAI $^{12}$, YI-JIUN WENG ${ }^{*}$, CHIH-YANG HUANG ${ }^{3,4,13 *}$ and LI-MIEN CHEN ${ }^{11 *}$ \\ ${ }^{1}$ School of Post-Baccalaureate Chinese Medicine, College of Chinese Medicine, ${ }^{2}$ Department of Biological Science and \\ Technology, ${ }^{3}$ Graduate Institute of Chinese Medical Science, ${ }^{4}$ Graduate Institute of Basic Medical Science, China Medical \\ University; ${ }^{5}$ Department of Chinese Medicine, China Medical University Hospital, Taichung; Departments of ${ }^{6}$ Clinical \\ Pathology and ${ }^{7}$ Anatomic Pathology, Buddhist Dalin Tzu Chi General Hospital, Chiayi; ${ }^{8}$ Department of Pathology, \\ School of Medicine, Tzu Chi University, Hualien; ${ }^{9}$ Department of Pathology, Changhua Christian Hospital, \\ Changhua; ${ }^{10}$ Division of Gastroenterology, Department of Internal Medicine, ${ }^{11}$ Department of Internal \\ Medicine, Armed Forces Taichung General Hospital; Departments of ${ }^{12}$ Healthcare Administration, \\ ${ }^{13}$ Health and Nutrition Biotechnology, Asia University, Taichung, Taiwan, R.O.C.
}

Received October 9, 2010; Accepted February 4, 2011

DOI: $10.3892 /$ or.2011.1323

\begin{abstract}
Currently, there are no diagnostic or metastatic markers that can be used in early diagnosis and treatment of human hepatocellular carcinoma (HCC). The aim of this study was to find a molecular marker that regulated migration and metastasis in HCC. We analyzed the gene expression of $\beta$-catenin, c-Myc and IL- 8 in human HCC tissue by RT-PCR and immunohistochemistry and analyzed five variously differentiated HCC cell lines by Western blotting and migration and invasion assays to find markers for $\mathrm{HCC}$ diagnosis and HCC metastasis. mRNA expression of $\beta$-catenin was significantly higher in the tumor area compared to the nontumor area and was more abundant in specimens of late-stage HCC. Immunohistochemistry revealed that the translocation of $\beta$-catenin into the nucleus was closely correlated with IL-8 protein levels and tumor stage. Similarly, the level of expression and nuclear translocation of $\beta$-catenin was greater in HA22T cells with high proliferative activity than in HCC cell lines with low proliferative activity (PLC, Hep3B, HepG2). Knockdown of the $\beta$-catenin gene with $\beta$-catenin antisense
\end{abstract}

Correspondence to: Dr Li-Mien Chen, Department of Internal Medicine, Armed Forces Taichung General Hospital, Taichung, Taiwan, R.O.C.

E-mail: bigmay228@hotmail.com

Dr Chih-Yang Huang, Graduate Institute of Basic Medical Science, China Medical University, No. 91, Hsueh-Shih Road, Taichung 404, Taiwan, R.O.C.

E-mail: cyhuang@mail.cmu.edu.tw

*Contributed equally

Key words: $\beta$-catenin, migration, hepatocellular carcinoma, HA22T, invasion oligonucleotides resulted in inhibition of cell migration and invasion of HA22T cells. Taken together, these results suggest that $\beta$-catenin may be a suitable diagnostic marker of metastasis in human HCC.

\section{Introduction}

Hepatocellular carcinoma (HCC) is one of the most frequent malignancies found in South China, Sub-Saharan Africa and Southeastern Asia, including Taiwan. HCCs are genetically heterogeneous neoplasms and this genetic heterogeneity correlates with a variety of etiological factors (1). The molecular mechanisms, however, remain largely unknown. Recent studies have revealed that neoplastic transformation of liver cells is due in large part to the aberrant expression of a number of genes, including activation of cellular oncogenes, inactivation of tumor suppressor genes and overexpression of growth factors (2). Once metastasis occurs it causes $90 \%$ of human cancer deaths (3). Therefore, finding the switch to metastasis stage is urgent to control tumor development.

Several classes of proteins involved in the tethering of cells to their surroundings in a tissue are altered in cells possessing invasive or metastatic capabilities. The affected proteins include cell-cell adhesion molecules (CAMs), notably members of the immunoglobulin and calcium-dependent cadherin families, both of which mediate cell-to-cell interactions, and integrins, which link cells to extra-cellular matrix substrates (4). The most widely observed alteration in cellto-environment interactions in cancer involves E-cadherin, a homotypic cell-to-cell interaction molecule ubiquitously expressed on epithelial cells. $\beta$-catenin, binds the cytoplasmic domain of cadherin along with the actin binding protein, to bridge the extracellular adhesive activity of cadherins with the underlying actin cytoskeleton (5). Tyrosine phosphorylation of $\beta$-catenin leads to its dissociation from the adherens complex and probable transfer of the protein to the cytosol where it 
exists in a soluble, monomeric state. Cytosolic $\beta$-catenin may subsequently be degraded or be translocated into the nucleus and regulate the downstream gene expression. The coupling between adjacent cells by E-cadherin bridges results in the transmission of antigrowth and other signals via cytoplasmic contacts with $\beta$-catenin to intra-cellular signaling circuits. The function of E-cadherin is apparently lost in a majority of epithelial cancers by mechanisms that include mutational inactivation of the E-cadherin or $\beta$-catenin genes, transcriptional repression or proteolysis of the extra-cellular cadherin domain $(6,7)$.

In recent years, many studies have shown that the Wnt signaling pathway plays a crucial role in tumorigenesis $(8,9)$. The central member of the Wnt pathway is $\beta$-catenin. Intracellular protein complexes, including Dishevelled (Dvl/Dsh), glycogen synthase kinase-3 $\beta$ (GSK-3 $\beta$ ), Axin and adenomatous polyposis coli (APC) protein regulate cytosolic $\beta$-catenin protein levels. Overexpression of $\beta$-catenin, due to either a non-functioning APC protein or to mutations that eliminate the phosphorylation sites within $\beta$-catenin, is associated with several human cancers, including colon carcinomas, melanomas, pilomatricomas and HCC (10-15).

$\beta$-catenin mutations were found to range from 9 to $75 \%$ in mouse liver tumors induced using chemical carcinogens (16). The expression level and mutation frequency of $\beta$-catenin have been reported to be different in HCC from different countries or regions. Especially, the rates of overexpression of $\beta$-catenin in the nuclei range from 2.4 to $24.8 \%$ in $\operatorname{HCC}(17,18)$. The reduction or loss of $\beta$-catenin might disrupt the stability and integrity of the E-cadherin-catenin complex and disturbs the cellular adhesive junction, resulting in cell proliferation, tumor invasion and metastasis (19). The clinical implication of aberrant $\beta$-catenin expression in $\mathrm{HCC}$, however, remains unclear (20). The purpose of this study was to investigate the role that $\beta$-catenin plays in HCC. We measured the expression levels of $\beta$-catenin in different histological grades of human HCC tissues and five different differentiated HCC cell lines (HA22T, PLC, Hep3B, HepG2 and normal chang liver cells) and investigated the correlation between $\beta$-catenin and metastasis in HCC.

\section{Materials and methods}

Specimens. We collected different histological grades of human HCC tissues obtained from 30 patients (23 men and 7 women) at the Changhua Christian Hospital, Changhua, Taiwan during the period 1998-2001. The specimens included grade I HCC $(n=6)$, grade II HCC $(n=17)$ and grade III HCC $(n=7)$. The patient ages ranged from 31 to 79 years. Disease history, tumor grade, tumor size and level of differentiation in each patient were obtained from the medical records.

Immunohistochemistry. Slides with human HCC tissue sections were placed on a rack and dried at $58^{\circ} \mathrm{C}$ overnight. The slides were dewaxed in xylene for $40 \mathrm{~min}$, rehydrated in graduated ethanol solutions for $30 \mathrm{~min}$, and finally placed in $\mathrm{ddH}_{2} \mathrm{O}$ for $10 \mathrm{~min}$. Endogenous peroxidase activity was blocked with $3 \%$ $\mathrm{H}_{2} \mathrm{O}_{2}$ for $13 \mathrm{~min}$. Slides were then rinsed with tap water for $15 \mathrm{~min}$, placed in pre-warmed citrate buffer $(0.01 \mathrm{M}$ citric acid, $\mathrm{pH}$ 6), heated in a microwave for $15 \mathrm{~min}$, and then allowed to cool to room temperature for $30 \mathrm{~min}$. The slides were then rinsed with PBS buffer for $10 \mathrm{~min}$. Non-specific binding was blocked with 5\% FBS for $10 \mathrm{~min}$. A 1:50 dilution of polyclonal $\beta$-catenin or IL-8 antibody (Santa Cruz Biotechnology, CA, USA) was then added to each slide and allowed to incubate at $37^{\circ} \mathrm{C}$ for $1 \mathrm{~h}$. The slides were then washed with PBS for $10 \mathrm{~min}$ followed by the application of a secondary antibody (dilution of 1:100; Santa Cruz Biotechnology) for $30 \mathrm{~min}$. The slides were then washed again using PBS buffer for $10 \mathrm{~min}$. Immunoreactivity was visualized with DAB chromogen (3,3'-diaminobenzidine) using a DAB substrate kit (Roche, Mannheim, Germany).

Cell culture and transfection. Chang liver cells were grown in Basal Medium Eagle (BME) (Sigma, St. Louis, MO, USA). Hep3B, HepG2 and PLC were grown in Minimum Essential Medium (MEM) (Sigma). HA22T was grown in Dulbecco's modified Eagle's medium (DMEM) (Sigma). All media were supplemented with $10 \%$ fetal bovine serum (FBS) (HyClone, Logan, UT, USA), $1 \%$ penicillin, $0.1 \mathrm{mM}$ non-essential amino acids, $1.5 \mathrm{~g} / 1$ sodium bicarbonate and $1 \mathrm{mM}$ sodium pyruvate at $37^{\circ} \mathrm{C}$ in $5 \% \mathrm{CO}_{2}$. Cells were seeded onto $100-\mathrm{mm}$ dishes in DMEM containing 10\% FBS. On the next day, the medium was replaced with serum-free medium with no penicillin. Antisense oligonucleotides were introduced into the cells in the indicated amounts (10 and $100 \mu \mathrm{M})$ using Lipofectamine $^{\mathrm{TM}} 2000$ (Invitrogen, Carlsbad, CA, USA) according to the manufacturer's guidelines. Six hours later, the cells were fed with fresh DMEM medium containing $10 \%$ FBS. The $\beta$-catenin antisense oligonucleotide sequence was TAAGAGCTTAACCACAACTG and the $\beta$-catenin sense oligonucleotide sequence was CAGTAACTGAATAGCTACCA (MDBio, Taipei, Taiwan).

Isolation and purification of total RNA. Total RNA was extracted from HCC tissues using the Ultraspec RNA Isolation System (Biotecx Laboratories, Houston, TX, USA) according to the manufacturer's instructions. Following homogenization, the homogenate was stored for $5 \mathrm{~min}$ at $4^{\circ} \mathrm{C}$ to permit the complete dissociation of nucleoprotein complexes. Then, $0.2 \mathrm{ml}$ of chloroform per $1 \mathrm{ml}$ of Ultraspec ${ }^{\mathrm{TM}}$ RNA was added. The samples were tightly covered, shaken vigorously for $15 \mathrm{sec}$, and then placed on ice at $4^{\circ} \mathrm{C}$ for $5 \mathrm{~min}$. The homogenate was then centrifuged at $12,000 \mathrm{~g}$ at $4^{\circ} \mathrm{C}$ for $15 \mathrm{~min}$. The resulting homogenate consisted of three phases: a lower organic phase and an inter-phase, each containing DNA and protein, and an upper aqueous phase containing RNA. About $500 \mu \mathrm{l}$ of the aqueous phase was carefully transferred to a fresh tube while taking care not to disturb the inter-phase. Isopropanol $(500 \mu \mathrm{l})$ was then added and mixed. The sample was then centrifuged at $12,000 \mathrm{~g}$ at $4^{\circ} \mathrm{C}$ for $30 \mathrm{~min}$. The supernatant was discarded. The pellet was washed twice with $1 \mathrm{ml}$ of $75 \%$ ethanol and then dried. The pellet was resolved in $0.1 \%$ of DEPC-treated $\mathrm{ddH}_{2} \mathrm{O}$. Quantitative and qualitative analyses were performed using spectrophotometry at $260 \mathrm{~nm}$. The extract integrity was assessed using 1.5\% agarose gel electrophoresis and the RNA was visualized using ethidium bromide staining.

Reverse transcription and polymerase chain reaction (RT-PCR). An aliquot of total RNA $(0.5 \mu \mathrm{g})$ was reverse 
transcribed using $0.5 \mu \mathrm{M}$ oligo(dT) primers in a reaction solution $(50 \mu \mathrm{l})$ containing $75 \mathrm{mM} \mathrm{KCl}, 50 \mathrm{mM}$ Tris- $\mathrm{HCl}$ (pH 8.3), $3 \mathrm{mM} \mathrm{MgCl}_{2}, 10 \mathrm{mM}$ DTT, $10 \mathrm{U}$ RNase inhibitor (Promega, Madison, WI, USA), $0.8 \mathrm{mM}$ total dNTPs, and $200 \mathrm{U}$ of Moloney murine leukemia virus (MMLV) reverse transcriptase (Promega). The sample was incubated at $42^{\circ} \mathrm{C}$ for $1 \mathrm{~h}$ and at $99^{\circ} \mathrm{C}$ for $5 \mathrm{~min}$ before chilling on ice for $10 \mathrm{~min}$. The RT product $(2 \mu \mathrm{l})$ was diluted with the PCR buffer $(50 \mathrm{mM} \mathrm{KCl}, 10 \mathrm{mM}$ Tris- $\mathrm{HCl}, 2 \mathrm{mM} \mathrm{MgCl}$ ) to a final volume of $50 \mu \mathrm{l}$ containing $0.5 \mu \mathrm{M}$ dNTPs (final concentration, $0.8 \mathrm{mM}$ ) and $0.5 \mathrm{U}$ of Taq DNA polymerase. Following the hot start $\left(5 \mathrm{~min}\right.$ at $\left.95^{\circ} \mathrm{C}\right)$, the samples were subjected to 30 cycles of denaturation at $95^{\circ} \mathrm{C}$ for $1 \mathrm{~min}$, annealing at primer annealing temperature for $1 \mathrm{~min}$, and extension at $72^{\circ} \mathrm{C}$ for $1 \mathrm{~min}$, followed by a final cycle of extension for $10 \mathrm{~min}$ at $72^{\circ} \mathrm{C}$. The reaction was then held at $4^{\circ} \mathrm{C}$. The $\beta$-catenin forward primer was GCCGGCTATTGTAGAAGCTG and the reverse primer was ACTAGTCGTGGAATGGCACC. The pHe7 forward primer was CTTCGAAAGGCAAGGAGGAA and the reverse primer was TGGCTCTACAATCCTCAGCA (MDBio). The PCR products were analyzed on $1.2 \%$ agarose gel electrophoresis and imaged using the Kodak Scientific ID Imaging System (Eastman Kodak Co., CT, USA).

Isolation of cytoplasmic/nuclear fractions and Western blot analysis. Cytoplasmic and nuclear fractions were isolated with extraction reagent lysis buffer A $(50 \mathrm{mM}$ Tris-base, $0.5 \mathrm{M} \mathrm{NaCl}, 1 \mathrm{mM}$ EDTA, $1 \%$ NP40, $1 \%$ glycerol, $1 \mathrm{mM}$ $\beta$-mercaptoethanol and proteinase inhibitor) and lysis buffer $\mathrm{B}$ (50 mM Tris-base, $0.5 \mathrm{M} \mathrm{NaCl}, 1 \mathrm{mM}$ EDTA, $1 \%$ glycerol and proteinase inhibitor). In brief, $5 \times 10^{6}$ cells were trypsinized (0.05\% trypsin/0.53 mM EDTA) and resuspended in $100 \mu \mathrm{l}$ lysis buffer B. After a 10-min ice-cold incubation, the lysates were centrifuged at 3,000 $\mathrm{g}$ to pellet the nuclei. After centrifugation, the supernatant was stored for use as the cytoplasmic fraction. The nuclei were lysed with $100 \mu \mathrm{l}$ of lysis buffer A. The cell lysate proteins were separated using 12\% SDS-PAGE and transferred to PVDF membranes. Residual protein sites were blocked in Tween/Tris-buffer saline (TBS) containing 5\% skim milk. The filters were incubated with primary antibodies $\alpha$-tubulin (NeoMarkers, Fremont, CA, USA), $\beta$-catenin and c-Myc (Santa Cruz Biotechnology) in TBS at the recommended concentrations $(200 \mathrm{ng} / \mathrm{ml})$ at $4^{\circ} \mathrm{C}$ overnight and incubated with secondary antibodies for $1 \mathrm{~h}$ at room temperature. Antibody reaction was visualized with enhanced chemiluminescence (ECL) reagent (21).

Wound healing assay. Cells were initially seeded uniformly onto 60-mm culture plates. An artificial wound was then carefully created by scratching the sub-confluent cell monolayer with a P-200 pipette tip. After $48 \mathrm{~h}$ of culture in DMEM supplemented with $1 \%$ serum, cell migration was observed using the eyepiece of a phase contrast microscope.

Migration assay. A Boyden chemotaxis chamber was employed in this assay. The upper and lower chambers were separated by polyvinyl-pyrrolidone-free polycarbonate membranes with $8-\mu \mathrm{m}$ pores (Neuro Probes, Gaithersburg, MD, USA). The lower wells of the chamber were filled with DMEM medium supplemented with $10 \%$ FBS. Cells were added to the upper wells in a suspension with serum-free DMEM. A membrane sheet separated the upper and lower wells. The Boyden chamber was incubated for $4 \mathrm{~h}$ at $37^{\circ} \mathrm{C}$ to allow cell migration and adherence to the membrane. The membrane was then stained with Giemsa stain and the number of cells was counted under microscopic visualization.

Invasion assay. In vitro invasion assay was performed with a Boyden chemotaxis chamber. The filter surfaces $(8 \mu \mathrm{m}$ pore size) were coated with $50 \mu \mathrm{g}$ Matrigel (BD, Franklin Lakes, $\mathrm{NJ}$, USA) for $4 \mathrm{~h}$ at room temperature. The coating uniformity was checked using Coomassie Brilliant Blue staining and lowpower microscope observation. The lower chamber was filled with $10 \%$ FBS DMEM medium. Cells were re-suspended in the upper chamber wells in serum-free DMEM medium. After $4 \mathrm{~h}$ incubation at $37^{\circ} \mathrm{C}$, the filter was gently removed from the chamber. The cells on the upper surface were removed with a cotton swab. Cells that had passed through the Matrigel and attached to the filter surface were fixed with methanol and then stained with Giemsa stain. Cells that adhered to the membrane were counted under microscopic visualization.

Statistical analysis. The immunohistochemistry data were analyzed using $\chi^{2}$ and Fisher's exact test. Western blot analysis, invasion and migration experiments were repeated three times at least, and results are presented as the mean \pm SEM, and statistical comparisons were made using the Student's t-test. $\mathrm{p}<0.05$ was considered significantly different.

\section{Results}

The elevation of $\beta$-catenin gene expression and translocation correlated with HCC grading in vivo. An RT-PCR assay was used to examine the level of $\beta$-catenin mRNA expression in 30 tissue samples of HCC (Fig. 1A, B). Although most of the samples showed elevated levels of $\beta$-catenin mRNA expression, mRNA expression was significantly higher in high-grade HCC samples than in moderate- or low-grade samples $(\mathrm{p}<0.01)$ (Fig. 1B).

There was a differential distribution in the level of $\beta$-catenin expression between different grades of HCC. In well-differentiated HCC cells (grade I) there were significantly higher levels of $\beta$-catenin in the cytoplasm and significantly less membrane-bound $\beta$-catenin than in moderately or poorly differentiated cells $(\mathrm{p}<0.01)$. In moderately differentiated HCC cells (grade II), $\beta$-catenin was mostly concentrated in the cytoplasm and on the cell membrane, although some was located in the nucleus. In poorly differentiated HCC cells (grade III), there were significantly higher levels of $\beta$-catenin in the nucleus and on the cell membrane than in welldifferentiated and moderately differentiated cells $(\mathrm{p}<0.05)$ (Fig. 1C, D, Table I).

Based on the above data, $\beta$-catenin had greater expression in tumor than non-tumor tissue. The translocation of $\beta$-catenin from the membrane or cytoplasm into nucleus correlated with the pathologic grade of HCC. The results of the immunohistochemical studies showed that the protein expression of interleukin- 8 regulated by $\beta$-catenin was higher in tumor than in non-tumor tissue. The protein distribution ratio ranged from $0 \%$ in grade I HCC to $29 \%$ in grade III HCC (Table II). 
A
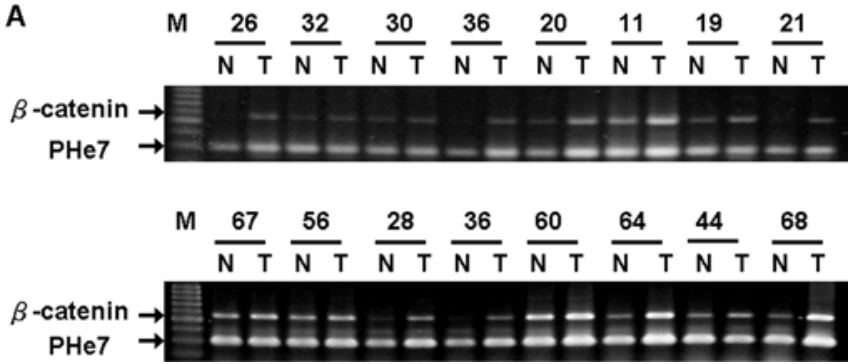

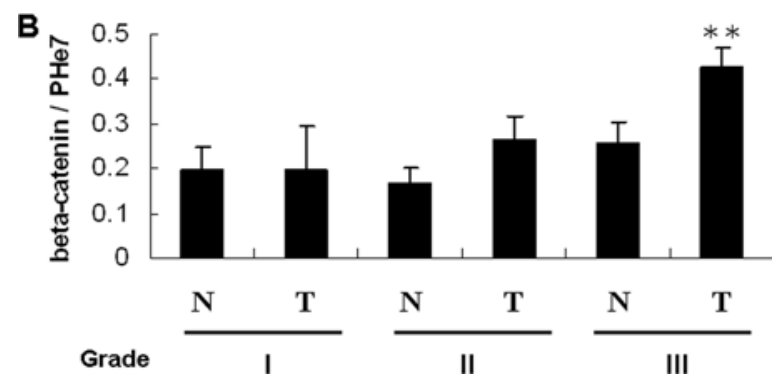

Grade

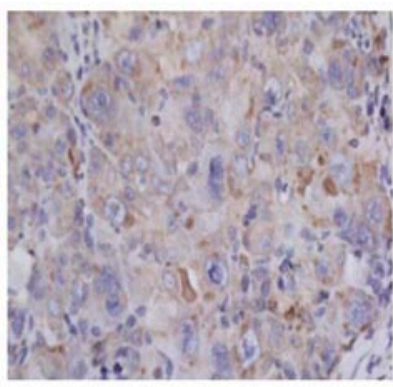

cytoplasmic type

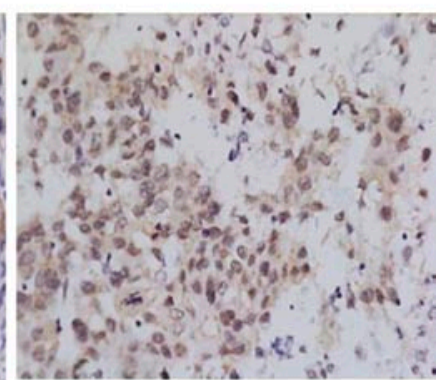

nuclear type membrane type

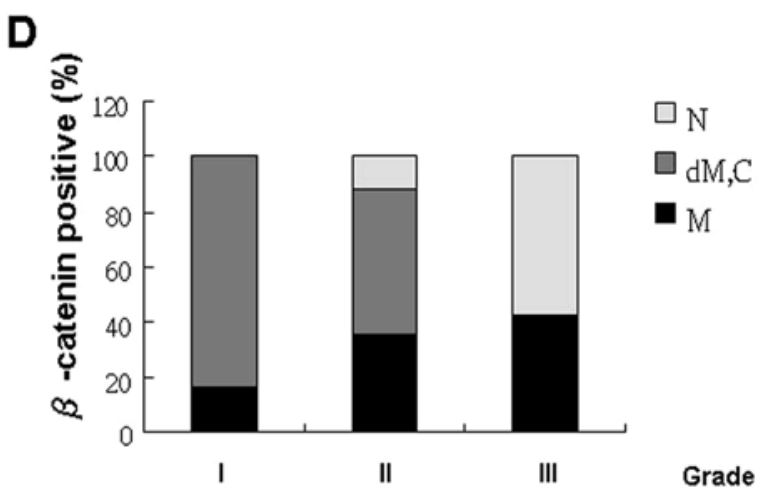

Table I. $\beta$-catenin protein distribution ratio in different grades of HCC.

\begin{tabular}{lccc}
\hline $\begin{array}{l}\beta \text {-catenin } \\
\text { Location }\end{array}$ & $\begin{array}{c}\beta \text {-catenin } \\
(\mathrm{dM}, \mathrm{C})(\%)\end{array}$ & $\begin{array}{c}\beta \text {-catenin } \\
\text { (nuclear) }(\%)\end{array}$ \\
\hline Grade I & $5 / 6(83)$ & $0 / 6 \quad(0)$ & $1 / 6(17)$ \\
Grade II & $8 / 17(47)$ & $2 / 17(12)$ & $7 / 17(41)$ \\
Grade III & $0 / 7 \quad(0)$ & $4 / 7(57)$ & $3 / 7 \quad(43)$ \\
\hline
\end{tabular}

Interleukin-8 might enhance angiogenesis, cell migration and metastasis. These findings suggest that $\beta$-catenin might be an important regulator in $\mathrm{HCC}$ metastasis.

Higher protein level and nuclear-type $\beta$-catenin were present in HA22T cells with high proliferative activity. To further confirm the in vivo correlation result, we used four differentiated HCC cell lines (HepG2, Hep3B, PLC, HA22T) ranging from well to poorly differentiated cells. Well-differentiated cells are present in lower grades of HCC and possess lower
Figure 1. Expression and protein distribution of $\beta$-catenin in different grades of HCC. (A) $\beta$-catenin gene expression in 30 samples of $\mathrm{HCC}$ from 30 patients were assayed by RT-PCR. PHe7 served as the internal control. (B) $\beta$-catenin gene expression was compared among 30 samples with different grades of HCC. N, non-tumor; T, tumor. (C) $\beta$-catenin protein distribution was assayed by immunohistochemistry. The $\beta$-catenin proteins were stained to show brown color in membrane, cytoplasm or nuclei. (D) Histogram of $\beta$-catenin protein distribution in different grades of HCC. N, nuclear; dM,C, diffuse membrane and cytoplasm; $\mathrm{M}$, cell membrane.

Table II. The IL-8 expression in different grades of HCC.

\begin{tabular}{lc}
\hline & IL-8 positive (\%) \\
\hline Grade I & $0 / 6(0)$ \\
Grede II & $2 / 17(11.8)$ \\
Grade III & $2 / 7(29)$ \\
\hline
\end{tabular}

proliferative activity. On the contrary, poorly differentiated cells are present in higher grades of HCC and have higher proliferative activity. We found that the protein level of $\beta$-catenin was highly expressed in HA22T cells, a cell line with high proliferative activity (Fig. 2A). To further test the correlation between $\beta$-catenin translocation and the development of HCC in vitro, we prepared nuclear and cytoplasmic protein fractions and assayed them using Western blot analysis. We found that the translocation of $\beta$-catenin into the nucleus was also negatively correlated with the degree of differentiation in HCC cells in vitro. Consequently, the level of $\beta$-catenin protein in the cytoplasmic fraction showed 
A

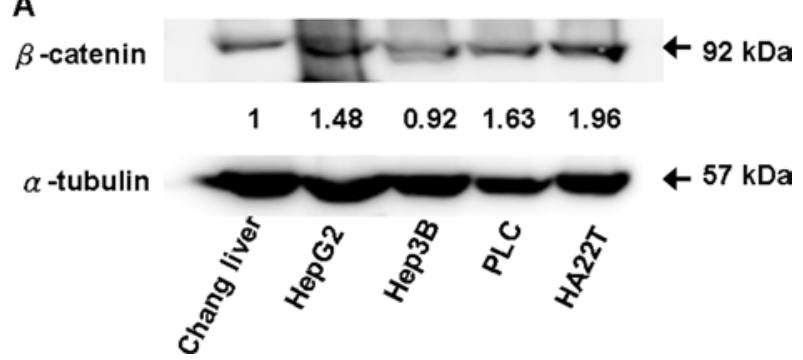

B

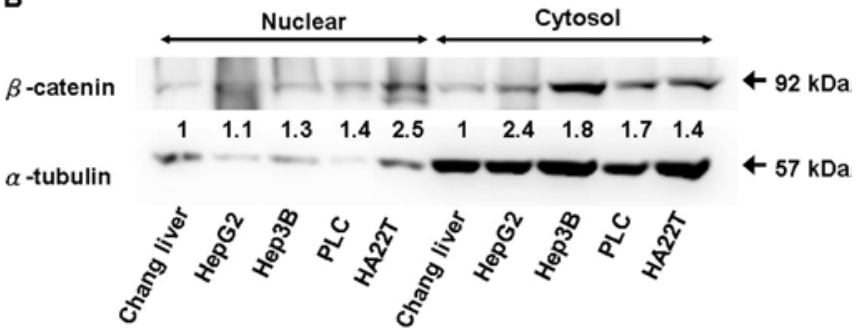

Figure 2. The protein level of $\beta$-catenin in five different differentiated HCC cell lines. (A) Chang liver, HepG2, Hep3B, PLC and HA22T cell lysates were prepared, and expression of $\beta$-catenin and $\alpha$-tubulin proteins were assessed by Western blot analysis. (B) The expression level of $\beta$-catenin protein in nuclear and cytosolic fractions was assayed by Western blotting.

A

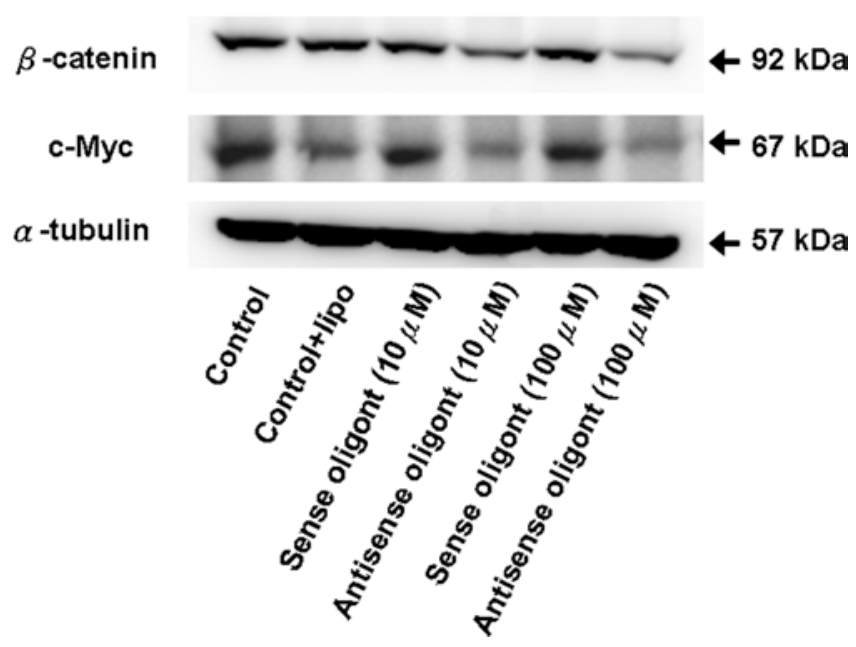

B

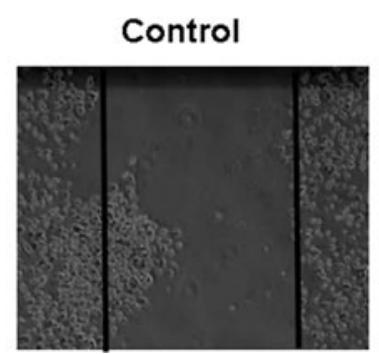

Sense oligont

$(10 \mu \mathrm{M})$

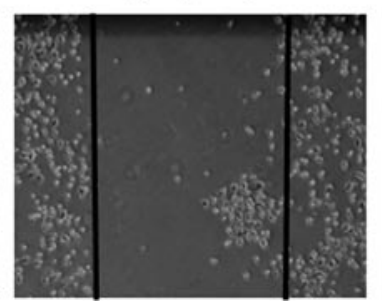

Antisense oligont $(10 \mu \mathrm{M})$

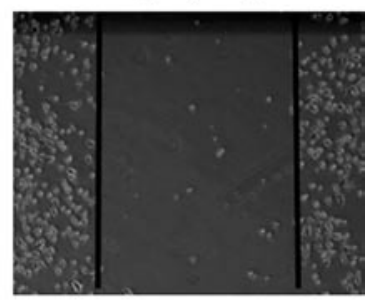

Figure 3. The protein level of $\beta$-catenin and c-Myc and the proliferation/migration effect after knockdown of $\beta$-catenin. (A) HA22T cells were transiently transfected with lipofectamine alone, $\beta$-catenin antisense or sense oligonucleotides at different dosages, as indicated. Expression of $\beta$-catenin, $\mathrm{c}$-Myc and $\alpha$-tubulin proteins was assessed using Western blot analysis. (B) HA22T cells were transiently transfected with lipofectamine alone, $\beta$-catenin antisense, or sense oligonucleotides at $10 \mu \mathrm{M}$ as indicated. The proliferation/migration effects of cells were assessed using wound healing assay for $48 \mathrm{~h}$. Sense oligonucleotides were used as a negative control; oligont, oligonucleotide.

negatively correlated with in the nuclear fraction (Fig. 2B). The HCC cells with high proliferative activity showed higher $\beta$-catenin protein levels and more translocation into the nucleus. All of these results suggest that nuclear accumulation of $\beta$-catenin is associated with the development of HCC both in vivo and in vitro.

Down-regulation of $\beta$-catenin reduces cell migration and invasion ability of HA22T cells. To explore whether $\beta$-catenin plays a key role in the metastasis of HCC, we applied $\beta$-catenin antisense oligonucleotides (10 or $100 \mu \mathrm{M})$ to knock down gene expression. The $\beta$-catenin antisense oligonucleotide treatment inhibited $\beta$-catenin and c-Myc expression in a dose-dependent manner (Fig. 3A). Knockdown of $\beta$-catenin with antisense oligonucleotides resulted in fewer proliferative and migrating cells in the wound-healing assay (Fig. 3B). In a further migration test using the Boyden chamber, knockdown of $\beta$-catenin reduced the number of migrating cells by about $50 \%$ $(\mathrm{p}<0.01)$ (Fig. 4A). Moreover, we employed a carcinogenic promoter, TPA, in the knockdown experiments. Knockdown 
A

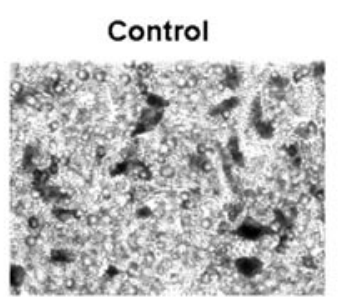

Sense oligont

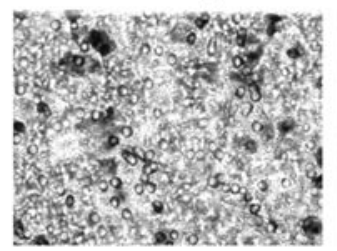

Antisense oligont

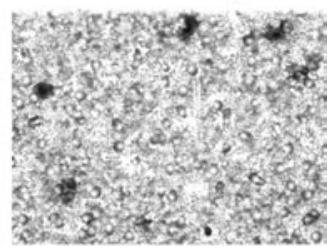

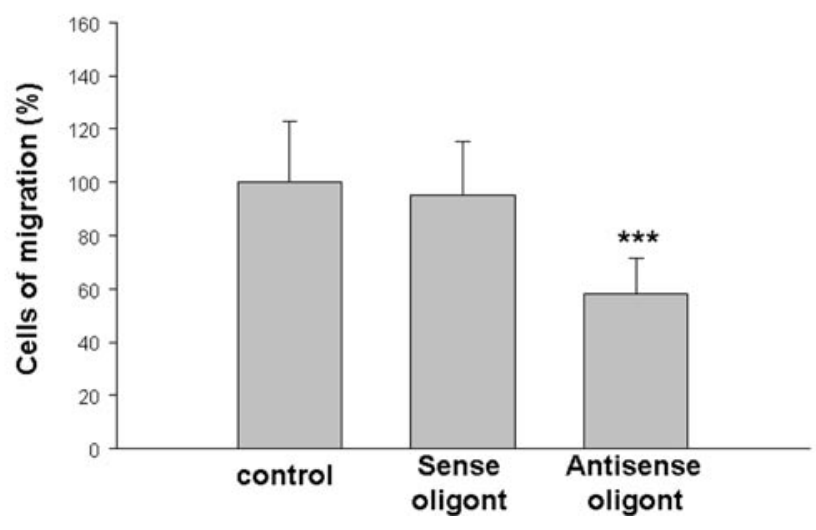

B

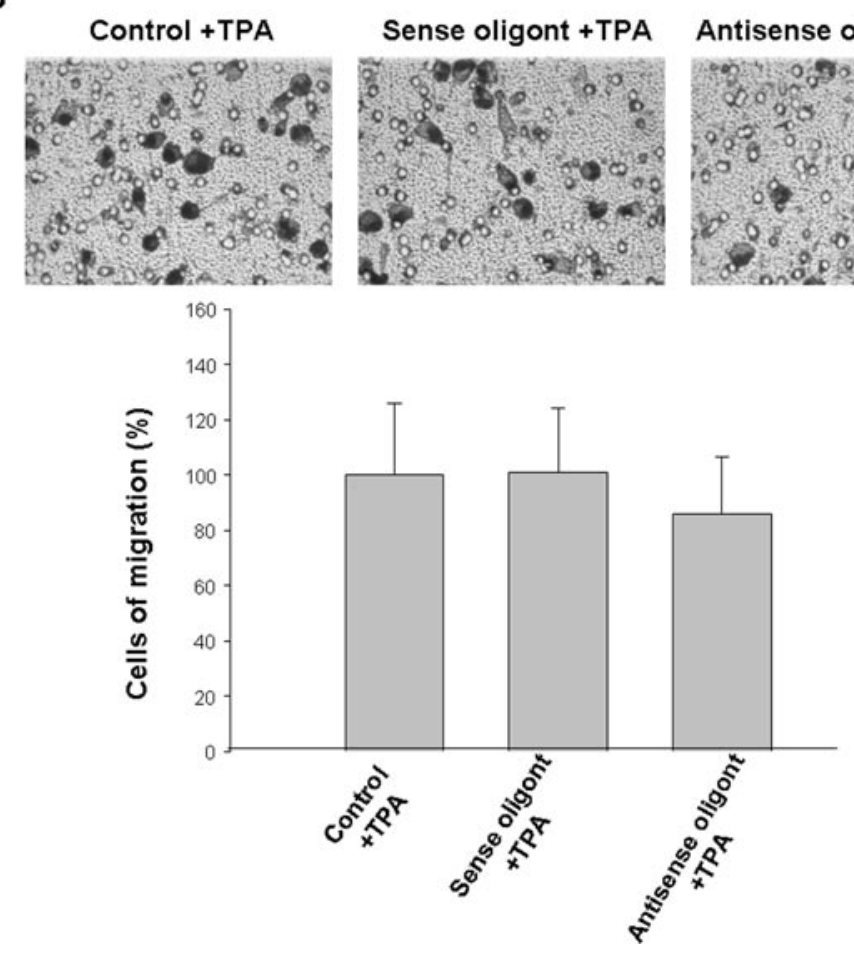

Figure 4. The migration effect of HA22T cells after knockdown of $\beta$-catenin with or without TPA. (A) HA22T cells were transiently transfected with lipofectamine alone, $\beta$-catenin antisense or sense oligonucleotides at $10 \mu \mathrm{M}$. Cell migration was assessed by Boyden chambers.

of $\beta$-catenin slightly reversed the TPA-induced migration effect (Fig. 4B). Treatment of HA22T cells with $\beta$-catenin antisense oligonucleotides resulted in a $50 \%$ reduction in cell invasion (Fig. 4C).

\section{Discussion}

There are no definitive molecular tools to characterize the biology of HCC, and most treatment decisions are still based on parameters such as size and tumor number, as defined by imaging techniques. Patients diagnosed at an early stage benefit from effective treatments such as surgical resection, transplantation, percutaneous ablation and palliative therapy. Survival of optimal candidates may exceed $60-70 \%$ at 5 years, the main drawback being the high rate of disease recurrence during follow-up ( $>50 \%$ at 3 years). After surgical ablation, numerous cases are susceptible to metastasis (22). Therefore, controlling the molecular factor of metastasis may be the suitable strategy after clinical surgery.

In this study, we showed that the mRNA level of $\beta$-catenin was significantly higher in tumor areas than in non-tumor areas, especially in pathologic grade III tumors. This finding 
C

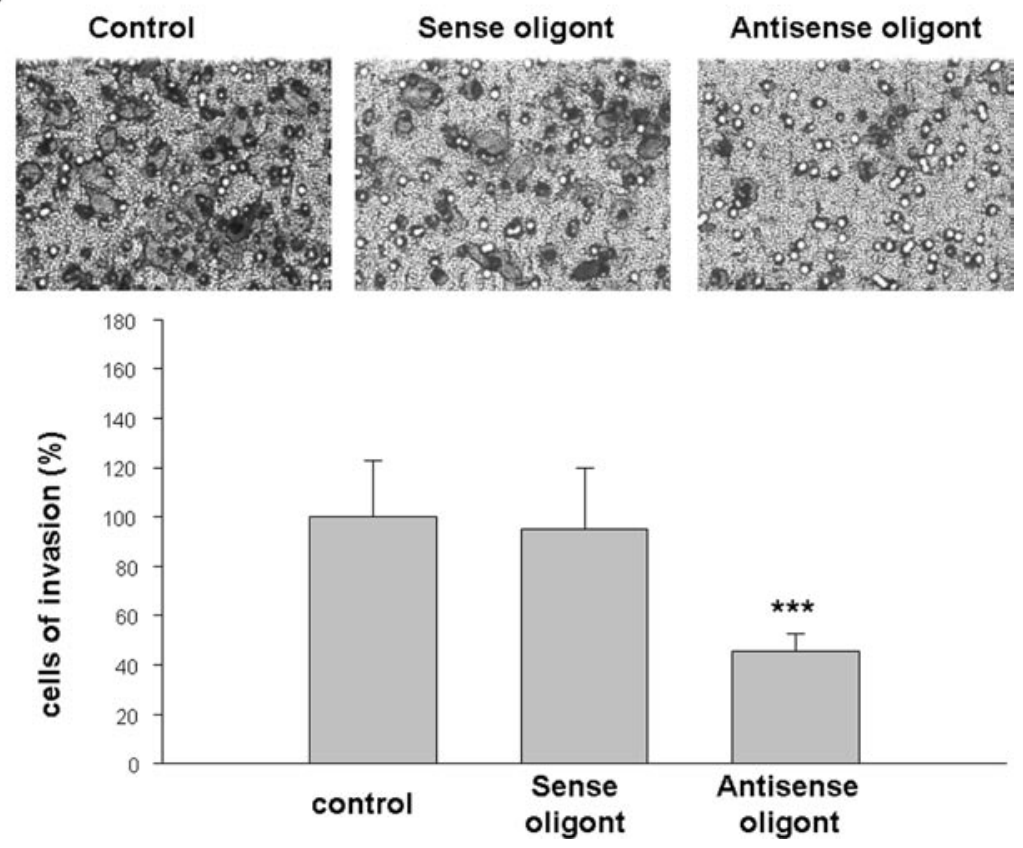

Figure 4. (C) The $\beta$-catenin knockdown effect on HA22T cell invasion. HA22T cells were transiently transfected with lipofectamine alone, $\beta$-catenin sense or antisense oligonucleotides at $10 \mu \mathrm{M}$. Cell invasion was assessed by Boyden chambers. The overall mean number of migrated cells from triplicate experiments is shown in the bar graph. ${ }^{* * *}$ Indicates significant difference $(\mathrm{p}<0.001)$; oligont, oligonucleotide.

suggests that $\beta$-catenin might be associated with HCC pathogenesis (Fig. 1A, B). Moreover, the translocation of $\beta$-catenin into the nucleus was closely associated with tumor development. The elevation of $\beta$-catenin expression was also correlated with poorly differentiated HCC (Fig. 1C, D and Table I). Similar results were found in vitro, in which $\beta$-catenin expression was greater in poorly differentiated HA22T HCC cells than in the other cell lines (Fig. 2A). We also found that the level of $\beta$-catenin expression increased as the level of cell differentiation decreased (Fig. 2A). In addition, our data show that the build up of $\beta$-catenin in the nucleus increased with disease progression, especially in HA22T cells, a cell line with high proliferative activity (Fig. 2B). In the poorly differentiated tumor area, we found an increase in $\beta$-catenin translocation to the nucleus and an increase in IL-8 expression (Table II), which suggests that $\beta$-catenin might play a major role in neovascularization, migration and tumor invasion $(23,24)$. Moreover, knockdown of $\beta$-catenin with antisense oligonucleotides resulted in decreased cell migration and invasion ability of the HA22T cells (Figs. 3 and $4 \mathrm{~A}, \mathrm{C}$ ). The above data suggest that $\beta$-catenin might be a key factor in metastasis of HCC.

The Wnt pathway regulates cell fate, proliferation and apoptosis $(25,26)$, and defects in the pathway play a key role in many cancers $(8-10,12,13,19)$. The degradation of $\beta$-catenin (in the absence of Wnt) involves binding of the protein to a complex involving adenomatous polyposis coli (APC) protein, and two further proteins, Axin and glycogen synthase kinase (GSK)-3 $\beta$. The latter serves to phosphorylate serine and threonine residues on $\beta$-catenin, a crucial step required to target the protein for ubiquitination and proteosomal degradation (8). Both APC and Axin enhance this phosphorylation step and are, therefore, promoters of $\beta$-catenin degradation. Mutations and abnormal expression of $\beta$-catenin were identified in numerous human cancers and correlated with tumor invasion and metastasis (19). A study by Miyoshi et al showed that APC is often inactivated and that exon 3 of the $\beta$-catenin gene is frequently mutated during hepatocellular carcinogenesis (27). The mutations in phosphorylation site of $\beta$-catenin exon 3 lead to accumulation of $\beta$-catenin in cytosol and translocation of activated $\beta$-catenin into nucleus (28). In our findings, we also show the translocation of $\beta$-catenin into nucleus and further point out the correlation with HCC grading (Fig. 1).

Recent studies have demonstrated that c-Myc, cyclin D1 and MMP-7 are important target genes of the Wnt signaling pathway and that overexpression of those genes is positively associated with the accumulation of $\beta$-catenin and mutational defects in the Wnt signaling pathway in numerous tumor types (10-18). Cyclin D1 and c-Myc are critical genes involved in cell proliferation and differentiation. As two target genes in the Wnt signaling pathway, the amplification or overexpression of c-Myc and cyclin D1 in tumor cells is extremely common, indicating that their activation may be essential during carcinogenesis $(19,29)$. We found that $\beta$-catenin antisense oligonucleotide treatment inhibited the expression of $\beta$-catenin protein and led to a decrease in the expression of c-Myc (Fig. 3A).

Additionally, the study of Bar-Eli (23) showed that IL-8 up-regulated MMP2 expression and activity and led to increased invasiveness of human melanoma cells. IL- 8 is an angiogenic factor up-regulated by hypoxia and related to metastasis of various primary tumors $(23,24)$. IL- 8 is associated with increased tumor growth and metastases in ovarian cancer (30). In this study, we showed that $\beta$-catenin was translocated into the nucleus and that this translocation was associated with increased expression of IL-8 (Fig. 1, Tables I and II), findings that suggest that enhancements of 
neoangiogenesis, migration and invasiveness lead to HCC metastasis. Collectively, our results suggest that $\beta$-catenin is not only important in controlling cell proliferation, but also is important in controlling HCC metastasis.

Based on our findings, we propose that $\beta$-catenin is anchored to the cell membrane under normal condition. Once the Wnt pathway is over activated or mutation occurs, $\beta$-catenin is gradually released into the cytosol causing the cells to detach from the extra cellular matrix and accumulating in the cytosol. $\beta$-catenin then translocates into the nucleus to function as a transcription factor that up-regulates c-Myc and IL-8 gene expression. When these genes are expressed, cell proliferation occurs and angiogenesis, cell migration, and metastasis are enhanced in HCC. For this reason, we hypothesize that $\beta$-catenin plays a key role in metastasis of HCC by up-regulating IL-8.

\section{References}

1. Pisani P, Parkin DM, Bray F and Ferlay J: Estimates of the worldwide mortality from 25 cancers in 1990. Int J Cancer 83: 18-29, 1999.

2. Yuan RH, Jeng YM, Chen HL, Hsieh FJ, Yang CY, Lee PH and Hsu HC: Opposite roles of human pancreatitis-associated protein and REG1A expression in hepatocellular carcinoma: association of pancreatitis-associated protein expression with low-stage hepatocellular carcinoma, beta-catenin mutation, and favorable prognosis. Clin Cancer Res 11: 2568-2575, 2005.

3. Sporn MB: The war on cancer. Lancet 347: 1377-1381, 1996.

4. Aplin AE, Howe A, Alahari SK and Juliano RL: Signal transduction and signal modulation by cell adhesion receptors. The role of integrins, cadherins, immunoglobulin-cell adhesion molecules, and selectins. Pharmacol Rev 50: 197-263, 1998.

5. Rimm DL, Koslov ER, Kebriaei P, Cianci CD and Morrow JS: Alpha $1(\mathrm{E})$-catenin is an actin-binding and -bundling protein mediating the attachment of F-actin to the membrane adhesion complex. Proc Natl Acad Sci USA 92: 8813-8817, 1995.

6. Christofori G and Semb H: The role of the cell-adhesion molecule E-cadherin as a tumour-suppressor gene. Trends Biochem Sci 24: 73-76, 1999.

7. Hanahan D and Weinberg RA: The hallmarks of cancer. Cell 100: 57-70, 2000.

8. Ban KC, Singh H, Krishnan R and Seow HF: GSK-3beta phosphorylation and alteration of beta-catenin in hepatocellular carcinoma. Cancer Lett 199: 201-208, 2003.

9. Lucero OM, Dawson DW, Moon RT and Chien AJ: A re-evaluation of the 'oncogenic' nature of Wnt/beta-catenin signaling in melanoma and other cancers. Curr Oncol Rep 12: 314-318, 2010.

10. Chan EF, Gat U, McNiff JM and Fuchs E: A common human skin tumour is caused by activating mutations in beta-catenin. Nat Genet 21: 410-413, 1999.

11. Miller JR, Hocking AM, Brown JD and Moon RT: Mechanism and function of signal transduction by the Wnt/beta-catenin and Wnt/Ca ${ }^{2+}$ pathways. Oncogene 18: 7860-7872, 1999.

12. Morin PJ, Sparks AB, Korinek V, Barker N, Clevers H, Vogelstein B and Kinzler KW: Activation of beta-catenin-Tcf signaling in colon cancer by mutations in beta-catenin or APC. Science 275: 1787-1790, 1997.

13. Rubinfeld B, Robbins P, El-Gamil M, Albert I, Porfiri E and Polakis P: Stabilization of beta-catenin by genetic defects in melanoma cell lines. Science 275: 1790-1792, 1997.
14. De La Coste A, Romagnolo B, Billuart P, Renard CA, Buendia MA, Soubrane O, Fabre M, Chelly J, Beldjord C, Kahn A and Perret C: Somatic mutations of the beta-catenin gene are frequent in mouse and human hepatocellular carcinomas. Proc Natl Acad Sci USA 95: 8847-8851, 1998.

15. Takigawa $\mathrm{Y}$ and Brown AM: Wnt signaling in liver cancer. Curr Drug Targets 9: 1013-1024, 2008.

16. Devereux TR, Anna CH, Foley JF, White CM, Sills RC and Barrett JC: Mutation of beta-catenin is an early event in chemically induced mouse hepatocellular carcinogenesis. Oncogene 18: 4726-4733, 1999.

17. Devereux TR, Stern MC, Flake GP, Yu MC, Zhang ZQ, London SJ and Taylor JA: CTNNB1 mutations and beta-catenin protein accumulation in human hepatocellular carcinomas associated with high exposure to aflatoxin B1. Mol Carcinog 31: 68-73, 2001.

18. Hsu HC, Jeng YM, Mao TL, Chu JS, Lai PL and Peng SY: Beta-catenin mutations are associated with a subset of low-stage hepatocellular carcinoma negative for hepatitis B virus and with favorable prognosis. Am J Pathol 157: 763-770, 2000.

19. Li YJ, Wei ZM, Meng YX and Ji XR: Beta-catenin up-regulates the expression of cyclinD1, c-myc and MMP-7 in human pancreatic cancer: relationships with carcinogenesis and metastasis. World J Gastroenterol 11: 2117-2123, 2005.

20. Joo M, Lee HK and Kang YK: Expression of beta-catenin in hepatocellular carcinoma in relation to tumor cell proliferation and cyclin D1 expression. J Korean Med Sci 18: 211-217, 2003.

21. Liu CJ, Cheng YC, Lee KW, Hsu HH, Chu CH, Tsai FJ, Tsai CH, Chu CY, Liu JY, Kuo WW and Huang CY: Lipopolysaccharide induces cellular hypertrophy through calcineurin/NFAT-3 signaling pathway in $\mathrm{H} 9 \mathrm{c} 2$ myocardiac cells. Mol Cell Biochem 313: 167-178, 2008.

22. Masuda T, Beppu T, Ishiko T, Horino K, Baba Y, Mizumoto T, Hayashi H, Okabe H, Horlad H, Doi K, Okabe K, Takamori H, Hirota M, Iyama $\mathrm{K}$ and Baba $\mathrm{H}$ : Intrahepatic dissemination of hepatocellular carcinoma after local ablation therapy. J Hepatobiliary Pancreat Surg 15: 589-595, 2008.

23. Bar-Eli M: Role of interleukin-8 in tumor growth and metastasis of human melanoma. Pathobiology 67: 12-18, 1999.

24. Takeda A, Stoeltzing O, Ahmad SA, Reinmuth N, Liu W, Parikh A, Fan F, Akagi M and Ellis LM: Role of angiogenesis in the development and growth of liver metastasis. Ann Surg Oncol 9: 610-616, 2002

25. Cadigan KM and Nusse R: Wnt signaling: a common theme in animal development. Genes Dev 11: 3286-3305, 1997.

26. Peifer $M$ and Polakis P: Wnt signaling in oncogenesis and embryogenesis - a look outside the nucleus. Science 287 : 1606-1609, 2000

27. Miyoshi Y, Iwao K, Nagasawa Y, Aihara T, Sasaki Y, Imaoka S, Murata M, Shimano T and Nakamura Y: Activation of the betacatenin gene in primary hepatocellular carcinoma by somatic alterations involving exon 3. Cancer Res 58: 2524-2527, 1998.

28. Cui J, Zhou XD, Liu YK, Tang ZY and Zile MH: Abnormal $\beta$-catenin gene expression with invasiveness of primary hepatocellular carcinoma in China. World J Gastroenterol 7: 542-546, 2001.

29. Wang W, Xue L and Wang P: Prognostic value of beta-catenin, c-myc, and cyclin D1 expressions in patients with esophageal squamous cell carcinoma. Med Oncol: Feb 9, 2010 (Epub ahead of print).

30. Shahzad MM, Arevalo JM, Armaiz-Pena GN, Lu C, Stone RL, Moreno-Smith M, Nishimura M, Lee JW, Jennings NB, Bottsford-Miller J, Vivas-Mejia P, Lutgendorf SK, LopezBerestein G, Bar-Eli M, Cole SW and Sood AK: Stress effects on FosB- and interleukin-8 (IL8)-driven ovarian cancer growth and metastasis. J Biol Chem 285: 35462-35470, 2010. 